\title{
MODELING THE DEPLOYMENT OF A FIRE STATION AND FIREHOUSE IN SELECTED AREAS OF THE SLOVAK REPUBLIC - THE DISTRICTS OF POVAZSKA BYSTRICA AND PUCHOV
}

Juraj JURDIK ${ }^{*}$

\section{Abstract}

There is a lot of legislative and theoretical knowledge about the deployment of fire stations and firehouses. Their placement in the Slovak Republic is, for the most part historical. Most of the dispatches from the fire stations and firehouses in the districts of Povazska Bystrica and Puchov are no longer than 2 hours. Evaluating the areas according to different methodologies provides similar results. It is necessary to involve voluntary and/or semiprofessional fire units in the rural or distant areas of the districts of Povazska Bystrica and Puchov.

\section{INTRODUCTION}

Adequate fire protection in terms of adequate spending is essential for a society. It needs to be carefully planned and consequently realized. To achieve a comprehensive, practical and feasible plan requires logical steps. In general, the planning of fire protection helps to improve the efficient operation of firefighters. Sufficient manpower and resources are also necessary to realize speedy and effective firefighting (Hanuska, 1998). Some degree of fire protection is usual in a location, which is why the planning process usually starts with an assessment of the existing fire protection. The aim of the risk assessment process is to determine the likelihood of an incident, as well as the potential consequences of this event.

The results of an analysis for the selected area should be specific for the deployment of fire units and fire stations. There should also be an estimate of the resources that are able to solve any emergency situation, including the determination of the type of fire brigade. Different types of fire departments have different equipment and procedures for the same type of incident. These are usually composed of intervention groups with different compositions of the crew, different ways of the infrastructure financing, and many other different factors in relation to the real situation.

\section{Address}

1 Fire and rescue services district directoriate Povazska Bystrica, Head of Operational and technical division, Stred 46/6, 01701 Povazska Bystrica

* Corresponding author: jurdik.juraj@gmail.com

\section{Key words}

- Fire units,

- fire stations,

- modelling deployments.

A village with a sufficient and effective fire unit is less exposed to fires and other negative impacts than a municipality with a less numerous and also technically equipped fire brigade. Along with the knowledge of this phenomenon, it is necessary to determine the size of the fire units with a focus on minimizing the consequences of fires and other emergencies and optimizing them according to the possible choices of a society and the degree of risk to individual municipalities (The City of Portland Oregon, 2008).

\section{MODELING CAPABILITIES}

\section{Response time}

The response time parameter is substantial for assessing the performance of a fire unit and, together with the time necessary to roll out for fires and incidents, for determining the unavailability of the fire unit for further action (Urban Fire Forum, 2011).

The average response time was 1 hour and 21 minutes for the fire station at Povazska Bystrica in 2014. This value is actually not too long when considered within the meaning of the principles of 
firefighting tactics for almost any operation for the time necessary to investigate the situation, intervene, and pick up the equipment. In practice, the response time is often prolonged by other factors, for example, the transfer to the location of the incident or assistance to the police and a towing service with a dangerous removal of a road barrier. In practice, 90 percent of the responses are dealt with in 2 hours and 22 minutes (Figure 1).

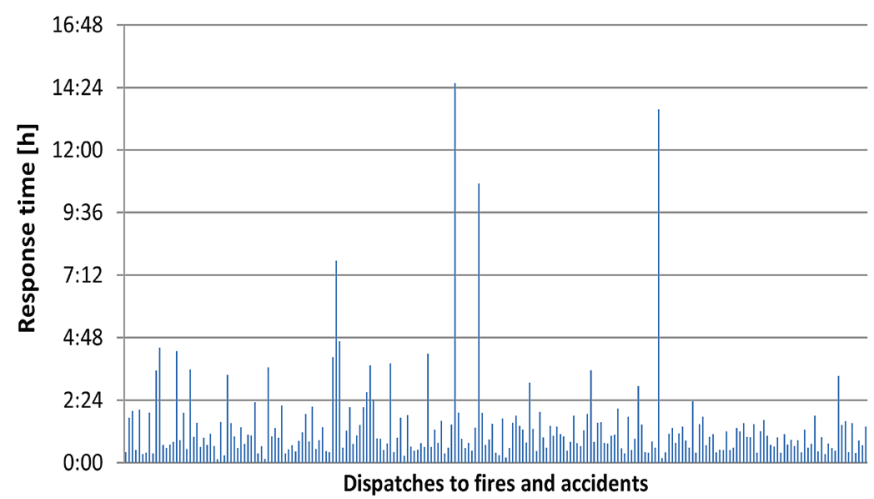

Fig. 1 Response time of the fire brigade at Povazska Bystrica to dispatches in the year 2014.

Most interventions will be disposed of within this time frame, apart from difficult technical responses and long-lasting fires. A significant use of this data is, in addition to assessing the availability of units, for example, the need for convening them to a state of readiness at the appropriate fire station. Convening units to a state of readiness appears in that time (which is usually within 1 hour) as less effective than a transfer of reinforcements from another fire station. This argument is, however, necessary to support with the distances and travel times between the fire stations in these towns $(17 \mathrm{~km}$ from Povazska Bystrica to Puchov, $17 \mathrm{~km}$ from Trencin to Dubnica, $17 \mathrm{~km}$ from Prievidza to Handlova, $25 \mathrm{~km}$ from Prievidza to Partizanske, 26 $\mathrm{km}$ from Trencin to Banovce nad Bebravou, $40 \mathrm{~km}$ from Trencin to Povazska Bystrica, $45 \mathrm{~km}$ from Trencin to Puchov, and $46 \mathrm{~km}$ from Trencin to Partizanske). With an average driving speed of $60 \mathrm{~km} / \mathrm{h}$ for a firetruck, all the variants are in a range of one hour (the average speed of fire engines may be even higher with respect to the use of new fire engines with higher speeds and the proximity of the Bratislava -Zilina motorway). It also provides an advantage in terms of the transport of additional firefighting equipment in the event of a sudden change in the situation facing the fire unit itself. Using volunteer fire brigades, which have significantly improved, is also possible.

\section{POSSIBLE SOURCES OF THREATS IN THE DISTRICTS OF POVAZSKA BYSTRICA AND PUCHOV}

1. Natural disasters (floods, landslides, storms, avalanches, earthquakes, etc.)

2. Accidents in industry (chemical, engineering, energy, etc.).

3. Transport of dangerous goods by rail and road communications

Interventions during natural disasters are difficult and require cooperation not only by rescue units, but also by governments and other organizations. It is difficult to estimate their direct impact.

\subsection{Selected complex building structures in the intervention area of the fire stations of Povazska Bystrica and Puchov in terms of fire units}

Dangerous structures and buildings can be divided into several groups:

1. civil structures that store dangerous substances

2. civil structures (buildings), in which operations and activities that have increased fire risks are provided

3. High-rise buildings and tall structures

4. separate buildings with assembly areas; buildings for people with reduced mobility

In the intervention area of the Povazska Bystrica fire station, the first group includes the following:

- an industrial zone (industrial area of, e.g., Povazske strojarne, KALIAREŇ Ltd., PSL, etc.)

- the Orlove light industry zone,

- an ice stadium,

- petrol stations in the town of Povazska Bystrica on Sladkovicova Street, the SNP complex and Zilina Street.

In the intervention area of the Puchov fire station the first group includes the following:

- the Continental Matador Rubber Company, the Continental and Matador Truck Tires companies,

- the Puchov meat industry plant,

- the Puchov ice stadium.

The buildings in Povazska Bystrica with a fire height of $22.5 \mathrm{~m}$ are - the VVZ and Diamon buildings,

- the District office building in Povazska Bystrica,

- 20 residential houses on the Rozkvet estate,

- 7 apartment buildings on the Lany estate. (The town planning scheme of the town of Povazska Bystrica, 2015; The town planning scheme of the town of Puchov, 2015).

\section{EVALUATION OF CADASTRAL AREAS ACCORDING TO THE METHODOLOGY USED IN THE CZECH REPUBLIC FOR THE DISTRICTS OF POVAZSKA BYSTRICA AND PUCHOV}

For determining the arrival time of fire brigades to locations, two different methodologies are used.

The deployment methodology used by fire brigades in the Czech Republic is in principle very similar to the methodology in the Slovak Republic. As the smallest territorial units, the cadastral areas of individual municipalities have been selected. In view of the increased demands on the fire brigade on the basis of the height and the complex of technology buildings, storage buildings, more flammable substances, or in buildings and complexes that appear to have large numbers of persons, it is possible to put such buildings into a category requiring severe measures.

According to the methodology used in the Czech Republic, it is required to cover most municipalities within the range of fire brigades in 15 to 20 minutes (Table 2).

A more complicated situation occurs in the municipalities included in the IIB severe category, where the required range for fire units is within ten minutes. The exception is the municipality of Udica, which is close to a professional firefighting unit. In the villages of Papradno and Domaniza, the first fire unit should be the local volunteer fire unit. 
Tab. 1 Number of fire units and arrivals according to arrea categories (Hanuska, 1998).

\begin{tabular}{|c|c|l|}
\hline \multicolumn{2}{|c|}{ Categories } & Number of fire units and roll out time to the scene \\
\hline \multirow{2}{*}{ I } & A & 2 fire units within 7 min and another fire unit in $10 \mathrm{~min}$ \\
\cline { 2 - 3 } & B & 1 fire unit within $7 \mathrm{~min}$ and another 2 fire units in $10 \mathrm{~min}$ \\
\hline \multirow{2}{*}{ II } & A & 2 fire units within 10 min and another fire unit in $15 \mathrm{~min}$ \\
\cline { 2 - 4 } & B & 1 fire unit within 10 min and another 2 fire units in $15 \mathrm{~min}$ \\
\hline \multirow{2}{*}{ III } & A & 2 fire units within 15 min and another fire unit in 20 min \\
\cline { 2 - 4 } & B & 1 fire unit within 15 min and another 2 fire units in $20 \mathrm{~min}$ \\
\hline IV & A & 1 fire unit within 20 min and another fire unit in $25 \mathrm{~min}$ \\
\hline
\end{tabular}

Tab. 2 Areas and categories according to the methodology used in the Czech Republic.

\begin{tabular}{|c|c|c|c|c|c|}
\hline \multicolumn{6}{|c|}{ District of Povazska Bystrica } \\
\hline Area & Category & Area & Category & Area & Category \\
\hline Bodina & IIIB & Jasenica & IIIA & Pruzina & IIIA \\
\hline Brvniste & IIIA & Kliestina & IIIB & Sadočne & IV \\
\hline $\begin{array}{l}\text { Celkova } \\
\text { Lehota }\end{array}$ & IV & Kostolec & IIIB & Slopna & IIIB \\
\hline $\begin{array}{l}\text { Dolna } \\
\text { Marikova }\end{array}$ & IIIA & $\begin{array}{l}\text { Male Led- } \\
\text { nice }\end{array}$ & IIIA & Stupna & IIIB \\
\hline $\begin{array}{l}\text { Dolny } \\
\text { Lieskov }\end{array}$ & IIIA & Papradno & IIB & Sverepec & IIIA \\
\hline Domaniza & IIB & $\begin{array}{l}\text { Plevnik - } \\
\text { Drienove }\end{array}$ & IIIA & Udica & IIB \\
\hline Durdove & IV & Pocarova & IV & Vrchtepla & IIIB \\
\hline Hatne & IIIB & Podskalie & IV & Zaskalie & IV \\
\hline $\begin{array}{l}\text { Horna } \\
\text { Marikova }\end{array}$ & IIIA & $\begin{array}{l}\text { Povazska } \\
\text { Bystrica }\end{array}$ & IIA & & \\
\hline $\begin{array}{l}\text { Horný } \\
\text { Lieskov }\end{array}$ & IIIB & Precin & IIIA & & \\
\hline \multicolumn{6}{|c|}{ District of Puchov } \\
\hline Puchov & IIA & Kvasov & IIIB & Mojtin & IIIB \\
\hline Belusa & IIB & $\begin{array}{l}\text { Lazy pod } \\
\text { Makytou }\end{array}$ & IIB & Nimnica & IIIA \\
\hline Dohnany & IIIA & Lednica & IIIB & Strezenice & IIIB \\
\hline $\begin{array}{l}\text { Dolna } \\
\text { Breznica }\end{array}$ & IIIB & $\begin{array}{l}\text { Lednicke } \\
\text { Rovne }\end{array}$ & IIB & Visolaje & IIIB \\
\hline $\begin{array}{l}\text { Dolne } \\
\text { Kockovce }\end{array}$ & IIIA & Luky & IIIB & Vydrna & IIIB \\
\hline $\begin{array}{l}\text { Horna } \\
\text { Breznica }\end{array}$ & IIIB & $\begin{array}{l}\text { Lysa pod } \\
\text { Makytou }\end{array}$ & IIIA & Zariecie & IIIB \\
\hline Horovce & IIIB & Mestecko & IIIB & Zubak & IIIB \\
\hline
\end{tabular}

According to the government-approved document "Draft of the nationwide deployment of forces and means of fire brigades in Slovakia," most of the municipalities of the Povazska Bystrica district are included in the least severe category of VII. The requirements for the range of units according to this methodology are less rigorous, but categories of cadastral areas are, with the exception of the nearby villages of Domaniza and Pruzina, very similar. For most of the cadastral areas it is necessary to organize the range of one fire brigade to twenty minutes and driving range for another to twenty-five. Those requirements can be arranged by an equipped volunteer fire unit. The longer time for the arrival of professional units, especially at the end of villages and valleys, can be thus replaced by an equipped and trained volunteer or semi-professional fire service. Similarly, as with the methodology used in the Czech Republic, the villages of Udica and Papradno are indicated. The evaluation criteria for the villages of Plevnik and Pruzina are, according to the total value of the criteria, also included in the more severe category with a one-run drive in 15 minutes and two other units within twenty minutes. Papradno and Pruzina are in the 20-minute range for the professional fire brigade.

According to the methodology used in most municipalities in the Czech Republic, a time of arrival between 15 and 20 minutes is required. According to the assessment of the individual cadastral areas of municipalities, most municipalities are in the III B category (the range for the first fire unit is within 15 minutes, and the other two fire units is up to 20 minutes). This category typically fits a developed municipality of 1000 inhabitants. Four municipalities, Dohnany, Dolné Kockovce, Nimnica and Lysa pod Makytou, fit into the IIIA category (two fire units within a range of 15 minutes and another within 20 minutes). The district of Puchov is not represented with any small villages and no other significant risks are classified in category IV. Three municipalities (Belusa, Lazy pod Makytou, Lednické Rovne) were classified in category IIB. In these municipalities one fire unit is needed within 10 minutes and two more in 15 minutes. In all three cases, there are developed departmental municipalities with higher populations, but also small industrial plants. These municipalities also have additional local villages. The village of Belusa is actually the third most populous municipality in Slovakia that is not a town. The industrialized town of Puchov is classified in the IIA category; according to the methodology, it is necessary to provide two fire units within 10 minutes and another in 15 minutes.

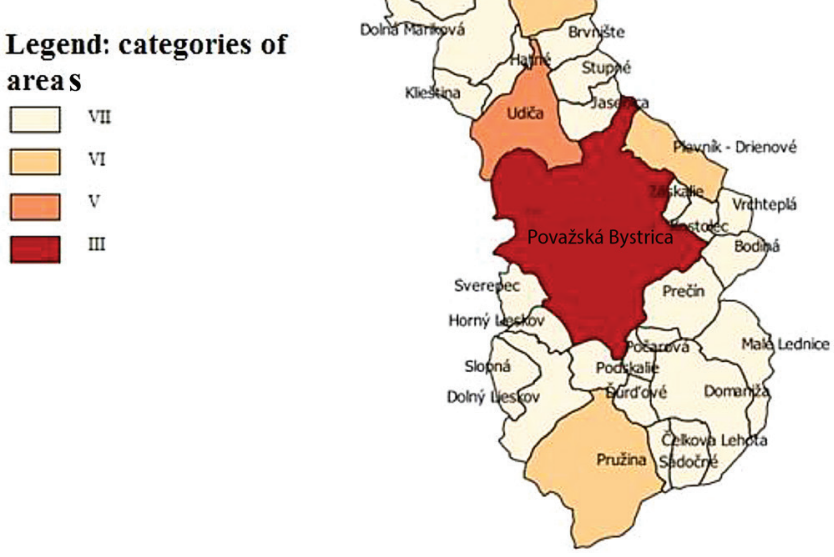

Map 1 Classification of municipalities in the district of Povazska Bystrica according to the Slovak government's approved methodology. 
According to the government-approved document "Areal deployment of forces and resources of fire brigades in the Slovak Republic" (UV-28103/2013).

Stringent requirements are less imposed on the range of fire brigades. The cadastral areas and particular structures are in similar categories as in the previous methodology.

Tab. 3 Number of fire units and arrivals according to the draft metodology for area categories in the Slovak Republic (UV28103/2013).

\begin{tabular}{|c|l|}
\hline Categories & Number of fire units and response times \\
\hline I & 2 fire units within 7 min and another fire unit in $10 \mathrm{~min}$ \\
\hline II & 1 fire unit within 7 and another 2 fire units in $10 \mathrm{~min}$ \\
\hline III & 2 fire units within 10 min and another fire unit in $15 \mathrm{~min}$ \\
\hline IV & 1 fire unit within 10 min and another 2 fire units in $15 \mathrm{~min}$ \\
\hline V & 2 fire units within 15 min and another fire unit in $20 \mathrm{~min}$ \\
\hline VI & 1 fire unit within 15 min and another 2 fire units in $20 \mathrm{~min}$ \\
\hline VII & 1 fire unit within 20 min and another fire unit in $25 \mathrm{~min}$ \\
\hline
\end{tabular}

Most of the municipalities of the district of Puchov are classified in category VII (Table 2). According to this classification, it is necessary to arrange one fire brigade within twenty minutes and another in twenty-five. Those requirements can be met by an equipped volunteer fire unit. The arrival time for professional units can be higher, especially for faraway villages and valleys; thus they can be replaced by equipped and trained volunteer or semi-professional fire services. According to this methodology Puchov and the municipality of Belusa, are classified in the more severe category IV, mainly due to their higher populations and the higher number of complex buildings. The required arrival time for the first fire unit is within 10 minutes and 15 minutes for another two units. It is possible to meet the demands with professional units in Puchov and the volunteer fire brigade in

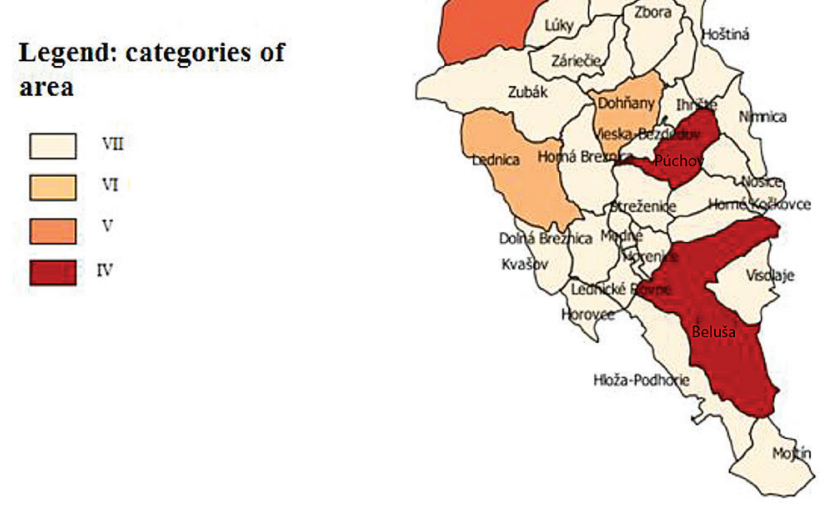

Map 2 Classification of municipalities in the district of Puchov according to the Slovak government's approved methodology. the village of Belusa. In Puchov, an active private fire unit has also been established for the CMR and CMTT a.s. companies. The village of Lednicke Rovne is, according to the criteria, in category V. The requirement is two fire units within 15 minutes. That can be arranged by the volunteer fire unit or the private fire unit in Rona a.s. and the professional unit from Puchov in 20 minutes. The village of Lysa pod Makytou is classified by the user criteria in the category VI. It can be taken care of by the local fire brigade, the fire department of the municipality of Luky, and the professional fire brigade from Puchov.

\section{MODELING THE DEPLOYMENT OF FIRE UNITS IN THE DISTRICTS OF POVAZSKA BYSTRICA AND PUCHOV}

A mathematical model of coverage was used for the coverage area of fire units within 15 minutes under the government-approved material (UV-28103/2013), similarly to the modeling of rescue service stations (Janosikova, 2007). This model assumes the predetermined maximum distance (in length or time units) between the "customer" (the person in distress) and the "center" (the fire unit). If the "center" is at a distance away from the "customer" in this limit, the "customer" is deemed to be covered and the service as acceptable.

The mathematical formulation of the model is then the following:

It is assumed that the possible sites for the deployment of fire stations were selected by the previous analysis. They are marked "J" as the set of these candidates for deployment. The features of this set are indexed by " $\mathrm{j}$ ". "I" marks the set of all the municipalities in a region and a single municipality. Both the I and $\mathrm{J}$ sets correspond to the nodes of the road network. NiᄃJ is the set of possible locations, which cover a municipality as well (i.e. distance from the village and at most 15 minutes). The bivalent variables $x j \in\{0,1\}$ model the decision as to whether a station will be located in the node $\mathrm{j}(\mathrm{xi}=1)$ or not $(\mathrm{xi}=0)$. The entry model is:

minimize

$$
Z=\sum_{j=J} x_{j}
$$

under the conditions

$$
\begin{array}{ll}
\sum_{j \in N_{i}} X_{j} \geq 1 & \forall i \in I \\
x_{j} \in\{0,1\} & \forall j \in J
\end{array}
$$

Function 1 minimizes the number of fire stations. Condition 2 requires that every village is covered by at least one fire station (Janosikova, 2007).

The data for the comparison, i.e., the response times and distance, were obtained from the freely available application "OpenStreetMap" (OpenStreetMap, 2015). The modeling program is written in Java. The selection was limited to municipalities with a population of more than 500 (for the establishment of a volunteer fire brigade in a village in the municipality under the legislation) (Act 314/2001).

\subsection{The output of the modeling program designed for the district of Povazska Bystrica}

The output of the proposed program is under the conditions of the smallest possible number of fire stations to ensure a range in each municipality in the district of Povazska Bystrica within the time limit of 15 minutes. This criterion is based on specified government-approved materials (UV-28103/2013) and, if necessary, is changeable 
in the program. The minimal number of stations is five for the fixed criterion. The concrete output is a pentad of municipalities in which the stations will be placed.

In the modeling program the input data of inserting and inputting the fire station to Povazska Bystrica provided the following results:

The maximum backup coverage of $90 \%$ of the population is in the settlements of the fire stations in Povazska Bystrica, Domaniza, Jasenica, Plevnik-Drienove, Pruzina and Dolna Marikova. Good coverage of the second unit of about $88 \%$ is ensured even when switching the village of Jasenica as the program input with the villages of Brvniste or Papradno. The exchange of the village of Pruzina by the village of Sverepec maintains coverage by the second unit to $87 \%$.

\subsection{The output of the modeling program designed for the district of Puchov}

The output of the proposed program is under the conditions of the smallest possible number of fire stations to ensure a range in each municipality in the district of Puchov within the time limit of 15 minutes. The minimal number of stations is three for the fixed criterion. The input data of the modeling for inserting and inputting the fire station for Puchov provided the following results:

The maximum backup coverage of $64 \%$ of the population is in the settlements of the fire stations in Belusa, Lednicke Rovne, Lazy pod Makytou, Luky (Lysa pod Makytou).

It is appropriate to place fire stations in the municipalities for the realization of such alternatives indicated by the index methodologies. These are Papradno and Pruzina for the fire district of Povazska Bystrica and Lysa pod Makytou for fire district of Puchov. The frequency of interventions for a newly-established fire station will be relatively low.
The alternative for territory coverage is to use selected volunteer firefighting teams with better equipment. The identification of several volunteer fire departments in municipalities with higher response times of the professional fire units can ensure early intervention when events are minor.

\section{CONCLUSION}

The response time of a fire unit is influenced by the deployment of fire stations and their staffing, including their technical equipment. The level of service in a municipality is given by the response time of the fire units and the arrival time of all the fire units on the scene. The concentration and the distribution of resources (fire units) are managed by the response time of the fire units and the arrival time of all the fire units on the scene. If the response times and force assembly times are low, that is an indicator that sufficient resources have been deployed and that the outcomes from risk events are more likely to be positive. Conversely, if the response times and force assembly times are high, that is an indicator of insufficient resources and that the outcomes from risk events are more likely to be negative.

There are several other considerations that must be taken into account when preparing the standards of response coverage for fire units. Often there are no simple or cheap solutions. In the districts of Povazska Bystrica and Puchov severe solutions were proposed by using a simple index methodology and a simple modeling program. 


\section{REFERENCES}

Act. 314/2001 Coll of 2 july 2001, About fire protection.

Hanuska, Z. (1998) Organizace jednotek požárni ochrany (Fire protection organization). Ostrava: SPBI, 1998, 98 pp. [in Czech].

Janosikova, L. (2007) Optimálne umiestnenie staníc záchrannej zdravotnej služby z hladiska dopravnej dostupnosti (Optimal ambulance stations and of placement services in terms of transport accessibility) Available from: http://frdsa.fri.uniza.sk/ janosik/ INFOTR.pdf (accessed at 02/02/2015).

OpenStreetMap (2015) Available from: http://owl.apis.dev.openstreetmap.org/\#map= 5/51.500/-0.100 (accessed at 02/02/2015).

Government material No. UV-28103/2013 Proposal of nationwide deployment of fire units in Slovakia.

The City of Portland Oregon (2008) PF\&R Standard of Emergency Response Coverage. Available from: http://www.portlandoregon. gov/fire/article/101052 (accessed at 02/02/2015).
The town planning scheme of the town of Povazska Bystrica (2015) Available from: http://www.uzemneplany.sk/upn/povazska-bystrica/uzemnyplanmesta/platny/text/sprievodna-sprava_(accessed at 02/02/2015).

The town planning scheme of the town of Puchov (2015) Available from: http://www.uzemneplany.sk/upn/povazska-bystrica/ uzemnyplanmesta/platny/text/sprievodna-sprava (accessed at 02/02/2015).

Urban Fire Forum (2011) Fire Service Deployment: Assessing Community Vulnerability. Available from: http:// www.darley.com/rokdownloads/insidedarley /jan12/assessing community vulnerability.pdf?phpMyAdmin $=09 \mathrm{ddb}-$ 9d90155752621e71754347eee7c (accessed at 02/02/2015). 